\title{
INVESTIGASI GERAKAN TANAH DAN AKUIFER MENGGUNAKAN METODE ELECTRICAL RESISTIVITY TOMOGRAPHY DI SEKITAR LERENG BGG - JATINANGOR
}

\author{
BUDY SANTOSO $^{* 1}$, SETIANTO ${ }^{2}$, IMRAN HILMAN MOHAMMAD ${ }^{1}$, RISDIANA ${ }^{2}$ \\ ${ }^{1}$ Departemen Geofisika, FMIPA, Universitas Padjadjaran \\ ${ }^{2}$ Departemen Fisika, FMIPA, Universitas Padjadjaran \\ Jl. Raya Bandung-Sumedang Km.21 Jatinangor 45363, Sumedang, Jawa Barat
}

*email : budi@geophys.unpad..ac.id

\begin{abstract}
Abstrak. Penelitian gerakan tanah dan akuifer telah dilakukan disekitar lereng Bandung Giri Gahana (BGG), Jatinangor, pada bulan Juni - November 2017. Faktor pemicu terjadinya gerakan tanah yaitu adanya batuan yang dapat berfungsi sebagai bidang gelincir serta lapisan pembawa air (akuifer). Bidang gelincir adalah bidang yang berada pada lapisan yang stabil dan bersifat kedap air (impermeable). Akuifer adalah lapisan batuan yang permeable baik yang terkonsolidasi atau yang tidak terkonsolidasi dengan kondisi jenuh air. Metode Geofisika yang dapat mengidentifikasi bidang gelincir dan akuifer yaitu Metode Geolistrik Electrical Resistivity Tomography (ERT). Berdasarkan hasil pengukuran ERT, bidang gelincir terdapat pada lempung pasiran dengan nilai resistivitas : $(50-78)$ Ohm.m, sedangkan bidang geser yang menyebabkan pergerakan tanah terdapat pada bahan rombakan dengan nilai resistivitas : (79 - 660) Ohm.m. Berdasarkan hasil pengukuran ERT, gerakan tanah yang terdapat dilokasi penelitian pergerakannya lambat sehingga dikategorikan ke dalam tipe rayapan. Lapisan pasir (akuifer) yang terdapat dibawah bidang geser memiliki resistivitas rendah dengan nilai : (9-25) Ohm.m.
\end{abstract}

Kata kunci : akuifer, bidang gelincir, bidang geser, ERT

\begin{abstract}
Land movement and aquifer studies have been conducted around the slopes of Bandung Giri Gahana (BGG), Jatinangor, from June to November 2017. The triggering factor of the land movement is the presence of rocks that can serve as a slip plane and the water carrier layer (aquifer). The slip plane is a plane that is in a stable layer and is impermeable. Aquifers are permeable rock layers either consolidated or unconsolidated with water-saturated conditions. Geophysical methods that can identify the slip plane and aquifer that is Electrical Resistivity Tomography (ERT) Method. Based on ERT measurement results, the slip plane area is found on the sandy clay with resistivity value: (50 - 78) Ohm.m, whereas the shear plane causing the movement of the soil is present in the revamp material with resistivity value: $(79$ - 660) Ohm.m. Based on the ERT measurement results, the movement of the soil in the location of the study is moving slowly so it is categorized into the type of creep. The sand layer (aquifer) contained below the shear plane has a low resistivity with values: $(9-25)$ Ohm.m.
\end{abstract}

Keywords : aquifer, slip plane, shear plane, ERT

\section{Pendahuluan}

Penelitian gerakan tanah dan akuifer yang dilakukan disekitar lereng Bandung Giri Gahana (BGG), Jatinangor, pada bulan Juni - November 2017 bertujuan untuk memperoleh data bidang gelincir, seperti jenis batuan bidang gelincir, resistivitas bidang gelincir dan kedalaman bidang gelincir. Salah satu faktor pemicu sehingga bidang gelincir dapat berfungsi, yaitu adanya air / lapisan pembawa air (akuifer). 
Gerakan tanah pada umumnya dapat terjadi karena kestabilan lereng berkurang akibat degradasi tanah, yaitu menurunnya sifat keteknikan tanah baik oleh faktor alam seperti meningkatnya curah hujan, adanya pelapukan atau akibat aktivitas manusia [1].

Indikasi bidang gelincir serta akuifer memiliki kontras resistivitas dibandingkan dengan resistivitas batuan disekitarnya. Salah satu metode geofisika yang dapat menentukan indikasi bidang gelincir dan akuifer yaitu Metode Geolistrik Electrical Resistivity Tomography (ERT). Bidang gelincir adalah bidang yang terletak dibawah bidang geser dan merupakan bidang yang stabil / tidak mudah bergeser. Hasil pengukuran. ERT dapat mencitrakan pergeseran lapisan batuan, posisi bidang gelincir serta akuifer berdasarkan resistivitas secara lateral dan vertikal.

Stratigrafi daerah penelitian termasuk ke dalam Formasi Hasil Gunung Api Muda Tak Teruraikan [2], terdiri dari : pasir tufaan, breksi dan aglomerat, sebagian berasal dari Gunung Tangkuban Parahu dan Gunung Tampomas, Batuan ini membentuk dataran-dataran kecil dan bukit-bukit rendah antara Sumedang dan Bandung.

\section{Metode Penelitian}

Bahan dan peralatan yang diperlukan dalam penelitian ini terdiri dari : bentonit (4 $\mathrm{kg}$ ), air garam (6 liter), elektroda (41 buah), kabel (8 gulung), accu 12V 50AH (1 buah), alat komunikasi (6 buah) dan main unit Resistivity Meter Naniura 300Hf Plus (1 buah).

Metode Geofisika yang digunakan dalam penelitian ini adalah Metode Geolistrik Electrical Resistivity Tomography (ERT). Metode ERT adalah Metode pengukuran resistivitas dipermukaan tanah / batuan dengan menggunakan banyak elektroda, agar diperoleh variasi distribusi resistivitas bawah permukaan secara lateral dan vertikal, sehingga didapatkan citra bawah permukaan [3]. Metode ERT banyak digunakan untuk eksplorasi dangkal seperti pendugaan akuifer dan mineral logam [4].

Pemilihan metode ERT dalam penelitian ini didasarkan atas hipotesis bahwa bidang gelincir, bidang geser dan akuifer memiliki kontras resistivitas terhadap resistivitas batuan sekitarnya. Adanya kontras resistivitas pada batuan memungkinkan pendugaan bidang gelincir, bidang geser dan akuifer dapat diketahui.

Data yang diperoleh dari hasil pengukuran ERT masih merupakan nilai resistivitas semu, utuk memperoleh nilai resistivitas sebenarnya maka dilakukan pengolahan data menggunakan perangkat lunak inversi Res2Dinv.

Pengukuran ERT dilakukan sebanyak dua lintasan, yaitu lintasan 1 (panjang $160 \mathrm{~m}$ dan jarak antar elektroda $4 \mathrm{~m}$ ), dan lintasan 2 (panjang lintasan $270 \mathrm{~m}$ dan jarak antar elektroda $10 \mathrm{~m}$ ), sedangkan kedalaman yang diperoleh adalah $20 \mathrm{~m}-40 \mathrm{~m}$.

Konfigurasi elektroda yang digunakan dalam pengukuran ERT, yaitu konfigurasi Wenner. Sistematika pengukuran ERT dengan konfigurasi Wenner ditunjukkan pada Gambar 1. Pada Gambar $1, \mathrm{C}_{1}$ dan $\mathrm{C}_{2}$ adalah pasangan elektroda arus, $\mathrm{P}_{1}$ dan $\mathrm{P}_{2}$ adalah pasangan elektroda potensial dan a adalah spasi antar elektroda dengan jarak yang sama. Konfigurasi Wenner memiliki resolusi data secara lateral yang sangat baik dibandingkan konfigurasi lainnya. Data yang diperoleh dalam 
pengukuran ERT, yaitu data resistivitas batuan. Nilai resistivitas batuan di daerah penelitian ditunjukkan pada Tabel 1 .

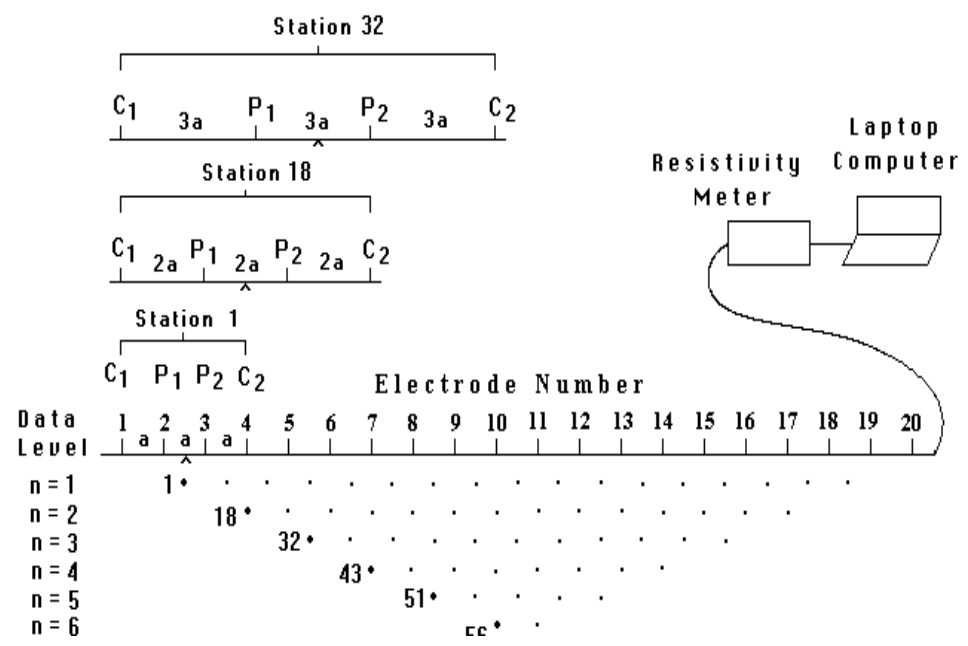

Gambar 1. Skema pengukuran ERT dengan konfigurasi Wenner [8]

Tabel 1. Nilai Resistivitas Batuan

\begin{tabular}{clc}
\hline No. & \multicolumn{1}{c}{ Jenis batuan } & $\begin{array}{c}\text { Resistivitas } \\
(\text { Ohm.m) }\end{array}$ \\
\hline 1 & Pasir (akuifer) & $9-25$ \\
2 & Pasirlempungan & $26-49$ \\
3 & Lempung & $50-78$ \\
& $\begin{array}{l}\text { Bahan rombakan, terdiri dari lempung / pasir } \\
\text { dengan fragmen batuan (kerikil, kerakal) dan } \\
\text { sedikit bongkah batuan }\end{array}$ & $79-660$ \\
\hline
\end{tabular}

Dalam metode resistivitas, sifat aliran listrik yang dipelajari adalah resistivitas batuan. Resistivitas batuan merupakan besaran fisika yang berhubungan dengan kemampuan suatu batuan dalam menghantarkan arus listrik. Lapisan batuan yang mempunyai nilai resistivitas rendah berarti mudah menghantarkan arus listrik, sebaliknya jika lapisan batuan mempunyai nilai resistivitas tinggi berarti sulit menghantarkan arus listrik. Pada Gambar 2 ditunjukkan skema pengukuran resistivitas. Arus listrik di injeksikan ke dalam bumi melalui dua elektroda arus $\mathrm{C}_{1}$ dan $\mathrm{C}_{2}$, kemudian respon beda potensial antara dua titik dipermukaan yang diakibatkan oleh aliran arus tersebut, diukur melalui dua elektroda potensial $\mathrm{P}_{1}$ dan $\mathrm{P}_{2}[5]$.

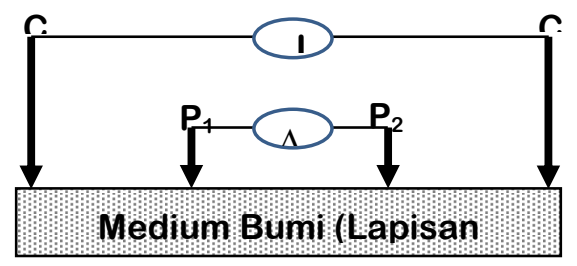

Gambar 2. Skema susunan elektroda arus dan potensial 
Berdasarkan nilai arus listrik (I) yang diinjeksikan dan beda potensial $(\Delta \mathrm{V})$ yang ditimbulkan, besarnya resistivitas $(\rho)$ dapat dihitung dengan persamaan rumus dibawah ini:

$$
\rho=K \frac{\Delta V}{I}
$$

Parameter K disebut faktor geometri. Faktor geometri merupakan besaran koreksi terhadap perbedaan letak susunan elektroda arus dan potensial. Nilai faktor geometri ini ditentukan oleh jenis konfigurasi elektroda yang digunakan. Konfigurasi elektroda yang digunakan dalam pengukuran resistivity, yaitu konfigurasi Wenner. Faktor geometri (K) konfigurasi Wenner dapat dihitung dengan persamaan (2), Konfigurasi elektroda yang digunakan dalam pengukuran resistivity, yaitu konfigurasi Wenner. Faktor geometri (K) konfigurasi Wenner dapat dihitung dengan persamaan (2).

$$
\mathrm{K}=2 \pi \mathrm{a}
$$

Nilai resistivitasnya dapat dihitung dengan persamaan (3).

$$
\rho s=2 \pi a \frac{\Delta \mathrm{V}}{\mathrm{I}}
$$

dengan $\rho$ s adalah resistivitas semu (Ohm.m), $\Delta \mathrm{V}$ adalah beda potensial (V), I adalah arus yang diinjeksikan (A), dan a adalah jarak antara elektroda (m).

Metode ERT dapat diterapkan untuk mencari akuifer (lapisan pembawa air) atau pendugaan bidang gelincir pada gerakan tanah. Akuifer adalah lapisan, formasi, atau kelompok formasi satuan geologi yang permeable baik yang terkonsolidasi (lempung, misalnya) maupun yang tidak terkonsolidasi (pasir) dengan kondisi jenuh air dan mempunyai suatu besaran konduktivitas hidraulik $(\mathrm{K})$ sehingga dapat membawa air (atau air dapat diambil) dalam jumlah (kuantitas) yang ekonomis [6]. Air dapat mengalir melalui beberapa jenis batuan, yaitu batuan yang tidak terkonsolidasi, batuan sedimen berpori, batuan vulkanik berpori, dan rekahan batuan/batuan retak.

Gerakan tanah adalah gerakan material pembentuk lereng berupa tanah, batuan atau kombinasi jenis material tersebut ke tempat yang lebih rendah karena pengaruh gaya gravitasi [6]. Gerakan tanah secara geologi terjadi karena beberapa faktor, yaitu :

a. faktor morfologi, diantaranya : punggung bukit yang curam dan retakan-retakan terbuka dalam tanah,

b. faktor struktur geologi, diantaranya : kekar dan sesar

c. faktor stratigrafi, diantaranya : adanya lapisan lunak di bawah lapisan keras dan adanya lensa-lensa pasir,

d. faktor jenis batuan, batuan sedimen lebih mudah lapuk dibandingkan dengan batuan beku,

e. faktor air, air hujan yang meresap ke dalam pori-pori / retakan batuan akan menambah massa batuan 
Gerakan tanah [7] diklasifikasikan sebagai berikut : jatuhan (falls), robohan (topples), rayapan tanah (soil creep), longsoran (slides), aliran (flows), dan gabungan (complex). Pada jenis jatuhan (falls), mekanisme gerakan massa tidak mengalami pergeseran dan umumnya bergerak melalui udara mencakup gerak jatuh bebas, loncatan atau menggelinding. Dari beberapa tipe pergerakan seperti tercantum di atas, jatuhan dan robohan umumnya terjadi pada lereng batuan dan lereng yang material pembentuknya tanah. Rayapan tanah (soil creep) adalah gerakan tanah yang sangat lambat dan sulit diamati secara langsung dan biasanya terjadi pada lereng landai. Longsoran (slides) adalah gerakan massa yang mengalami pergeseran sepanjang satu atau beberapa bidang permukaan. Tipe ini pergeserannya melalui bidang gelincir berupa kurva lengkung atau bentuk planar. Aliran (flow), pada jenis ini umumnya material longsoran berupa campuran tanah dan batu berupa lumpur dan bergerak sangat cepat.

\section{Hasil dan Pembahasan}

Hasil yang diperoleh dalam penelitian ini yaitu dua buah penampang resistivitas, terdiri dari : penampang resistivitas lintasan 1 posisinya di lereng jalan antara Bandung Giri Gahana (BGG) dengan Unpad, dan penampang resistivitas lintasan 2 posisinya berada dibawah lereng.

Resistivitas batuan yang diperoleh dari pemodelan resistivitas berkisar antara : (9 660) Ohm.m. Resistivitas tinggi (mendekati 660 Ohm.m) mengindikasikan batuannya bersifat padat / keras dan resistif, sedangkan resistivitas rendah (mendekati 9 Ohm.m) mengindikasikan batuannya semakin lunak dan semakin konduktif. Kedalaman lapisan batuan yang diperoleh dari hasil pemodelan resistivitas, yaitu : lintasan 1 kedalaman maksimal $20 \mathrm{~m}$ dan lintasan 2 kedalaman maksimal $40 \mathrm{~m}$.

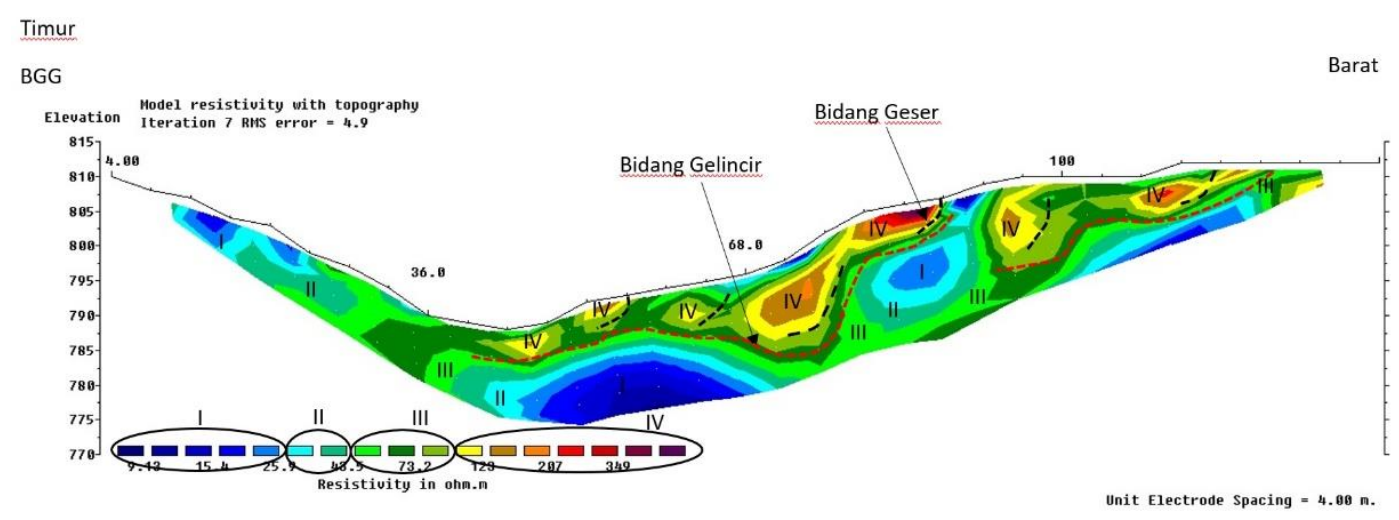

Gambar 3. Penampang Resistivitas Lintasan 1

Pada Gambar 3 menampilkan penampang resistivitas lintasan 1. Pada lapisan paling atas terdapat pola melensa yang diduga bidang geser / bidang pergerakan tanah terdapat pada jarak : (44 - 120) $\mathrm{m}$, jenis batuannya merupakan bahan rombakan, terdiri dari : Lempung / pasir dengan fragmen batuan (kerikil, kerakal) dan sedikit bongkah batuan dengan nilai resistivitas : $(79$ - 660) Ohm.m. Lapisan dibawah bidang geser terdapat resistivitas dengan nilai : $(50-78)$ Ohm.m yang diindikasikan sebagai lempung pasiran. Lapisan lempung pasiran berfungsi sebagai bidang 
gelincir karena bersifat semi kedap air, artinya air yang masuk ke lapisan tersebut masih bisa diteruskan ke lapisan dibawahnya tetapi pergerakannya sangat lambat. Pada lapisan paling bawah pada jarak : $(44-68) \mathrm{m}$ terdapat resistivitas dengan nilai : $(9$ - 25) Ohm.m yang diduga lapisan pasir, lapisan ini mengandung air sehingga dikategorikan sebagai akuifer. Air yang terdapat pada lapisan akuifer diantaranya berasal dari air permukaan yang masuk melalui rekahan batuan pada jarak $92 \mathrm{~m}$ dan $122 \mathrm{~m}$.

Sudut kemiringan lereng pada lintasan 3 kurang dari $30^{\circ}$ (tidak terlalu curam), sehingga gerakan tanah yang terjadi pergerakannya relatif lambat. Berdasarkan penampang resistivitas, gerakan tanah jenis rayapan yang terdapat pada lereng tersebut pergeserannya sangat lambat dan kondisi lereng relatif masih stabil.

Pada Gambar 4 menampilkan penampang resistivitas lintasan 2. Posisi lintasan 2 berada dibawah lereng. Pada lapisan paling atas terdapat resistivitas sedang dengan nilai : $(26$ - 36) Ohm.m yang diduga tanah timbunan terdapat pada jarak (120 150). Pada lapisan dibawahnya dengan kedalaman : $(9-22) \mathrm{m}$ terdapat resistivitas rendah dengan nilai : $(9-25)$ Ohm.m yang diduga sebagai lapisan pasir. Lapisan pasir tersebut diduga mengandung air tanah yang mengalir dari Bandung Giri Gahana (BGG) (Utara) menuju Selatan ke arah Jalan Raya Bandung-Sumedang. Pada lapisan paling bawah diindikasikan sebagai Batulempung dengan nilai resistivitas : $(50-78)$ Ohm.m, lapisan ini bersifat impermeable (kedap air), keras / padat dan kenyal sehingga lapisan ini tidak mudah bergeser/stabil.

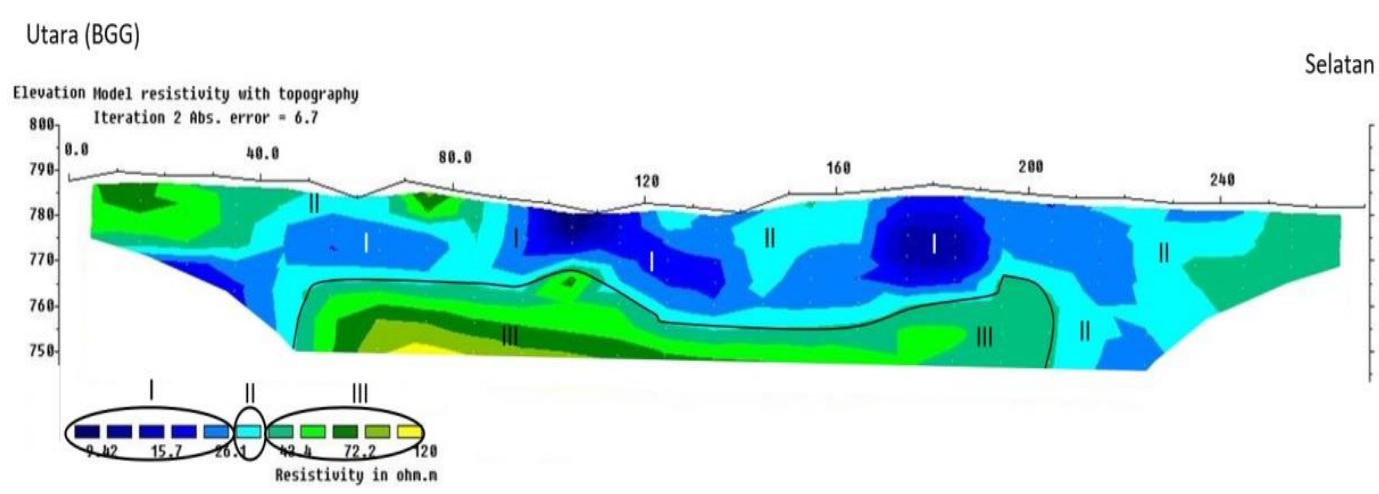

Gambar 4. Penampang Resistivitas Lintasan 2

Pergerakan tanah di daerah penelitian prosesnya lambat sehingga dikategorikan sebagai rayapan tanah, hal ini bisa dilihat pada lapisan paling atas (pada penampang resistivitas lintasan 1, warna : kuning-coklat- merah), dimana lapisannya sudah ada yang terpisah atau bergeser. Pergeseran tanah pada lapisan ini masih sedikit karena daya dukung tanahnya masih cukup baik.

Proses pergeseran tanah di daerah penelitian dapat dijelaskan sebagai berikut :

a. Air hujan yang turun akan masuk melalui lapisan tanah penutup dan rekahan batuan.

b. Air tersebut akan terus mengalir terus ke lapisan dibawahnya sampai dengan lapisan yang kedap air atau semi kedap air. 
c. Lapisan semi kedap air pada lapisan 1 terdapat pada lapisan lempung pasiran.

d. Pada lapisan lempung pasiran, air yang diteruskan ke lapisan dibawahnya sangat sedikit / infiltrasinya rendah sekali, sehingga air pada lapisan tersebut volumenya akan semakin banyak dan akan naik mendekati permukaan sampai dengan kondisi jenuh air, sedangkan sebagian lagi air tersebut akan mengalir ke bawah searah kemiringan lereng.

e. Kondisi jenuh air pada lapisan tanah akan mengakibatkan daya dukung tanah berkurang, sehingga gaya lapisan tanah yang bergerak menuruni lereng akan lebih besar dibandingkan gaya lapisan tanah yang menahan pergerakan tanah yang ada diatasnya, oleh karena itu terjadilah pergerakan tanah / longsor.

f. Pada lintasan 1 daya dukung tanahnya relatif masih baik, sehingga pergeseran / pergerakan tanahnya lambat. Kondisi daya dukung tanah akan selalu berubah tergantung dari curah hujan yang turun dilokasi tersebut.

Berdasarkan hasil pemodelan resistivitas pada masing-masing lintasan ERT, maka diperoleh indikasi akuifer dan jenis akuifernya.

\section{a. Akuifer Lintasan 1}

Akuifer pada lintasan 1 termasuk dalam kategori Perched Aquifers. Perched Aquifers merupakan akuifer yang terletak diatas suatu lapisan kedap air, biasanya terletak bebas pada suatu struktur tanah dan tidak berhubungan dengan sungai [6]. Lapisan kedap air pada Perched Aquifers diduga lempung dengan nilai resistivitas : $(50-78)$ Ohm.m. Air yang terdapat pada lapisan ini mengalir searah lereng menuju lembah

\section{b. Akuifer Lintasan 2}

Berdasarkan hasil pengukuran ERT, pada lintasan 2 terdapat indikasi akuifer dengan nilai resistivitas : $(9-25)$ Ohm.m. Akuifer ini terdapat pada lapisan pasir dengan kedalaman : $(9-22) \mathrm{m}$. Jenis akuifer pada lintasan 1 termasuk dalam kategori akuifer lembah (Valley Aquifers). Akuifer lembah merupakan akuifer yang ada pada suatu lembah dengan sungai sebagai batas (inlet atau outletnya). Jenis ini dapat dibedakan berdasarkan lokasinya yaitu di daerah yang banyak curah hujannya, seperti di Indonesia. Pengisian air terjadi pada seluruh area dari akuifer melalui infiltrasi [6].

\section{Kesimpulan}

Gerakan tanah yang terjadi di lereng Bandung Giri Gahana (BGG), Jatinangor, pergerakannya lambat sehingga diklasifikasikan sebagai rayapan tanah. Material yang mengalami pergeseran / pergerakan berupa bahan rombakan terdiri dari : lempung / pasir dengan fragmen batuan (kerikil, kerakal) dan sedikit bongkah batuan dengan nilai resistivitas : (79 - 660) Ohm.m. Pergeseran / pergerakan bahan rombakan terjadi karena adanya bidang gelincir dengan jenis batuannya lempung pasiran yang memiliki nilai resistivitas : $(50-78)$ Ohm.m. Bidang gelincir dapat berfungsi dengan baik karena adanya air / lapisan pembawa air (akuifer). Akuifer didaerah penelitian terdapat pada lapisan pasir dengan nilai resistivitas : $(9-25)$ Ohm.m pada kedalaman $\pm 15 \mathrm{~m}$. 


\section{Ucapan terima kasih}

Penulis mengucapkan terima kasih kepada Direktur DRPMI Unpad dan Kepala Pusat Studi Geofisika Eksplorasi Sumber Daya Mineral dan Lingkungan yang telah mengizinkan dan membiayai kegiatan penelitian ini.

\section{Daftar Pustaka}

1. K. Sugianti, Pengaruh Muka Air Tanah Terhadap Kestabilan Lereng Pada Ruas Jalan Raya Cadas Pangeran, Sumedang. Jurnal Riset Geologi dan Pertambangan, Vol. 22 No. 2 ( 2013) p.105-125.

2. P. H. Silitonga. Peta Geologi Lembar Bandung, Jawa. Pusat Penelitian dan Pengembangan Geologi (1973).

3. B. Santoso, B. Wijatmoko, E. Supriyana, A. Harja, Penentuan Resistivitas Batubara Menggunakan Metode Electrical Resistivity Tomography dan Vertical Electrical Sounding. Jurnal Material dan Energi Indonesia. Vol. 6 No. 1 (2016) p. 8-14.

4. J. M. Reynolds, An Introduction to Applied and Environmental Geophysics, New York, John Willey and Sons (1998).

5. W. M. Telford, L. P. Geldart, R.E. Sheriff, Applied Geophysics, New York, Cambridge (1990).

6. R. J. Kodoatie, Pengantar Hidrogeologi. Andi Yogyakarta (1995).

7. D. J. Varnes, Slope Movement Types and Processes, Landslide analysis and Control (1978).

8. M. H. Loke, Tutorial: 2D and 3D Electrical Imaging Surveys, http://www.geoelectrical.com (2004). 